\title{
LOS EFECTOS VINCULANTES DE LA PUBLICIDAD COMERCIAL EN LA CONTRATACIÓN CON CONSUMIDORES EN EL DERECHO DE NICARAGUA
}

\author{
Ángel Acedo Penco \\ Profesor de Derecho Civil, Universidad de Extremadura \\ angel@acedoabogados.com
}

\begin{abstract}
A mis entrañables alumnos, y a los responsables, de la $V$ Maestría en Derecho de Empresas con especialización en Asesoría Jurídica a Empresas, por la excelente y gentil hospitalidad con la que me obsequiaron durante mi breve paso por tan acogedoras aulas
\end{abstract}

Resumen: El trabajo analiza los precedentes del Derecho comunitario europeo en materia de protección de los consumidores y se adentra en el problema de la vinculación publicitaria de la oferta del empresario y su integración en el contrato, primero en el Derecho de España, con sus antecedentes legislativos y jurisprudenciales, y luego en el Derecho de Nicaragua, particularmente, en las normas vigentes de protección jurídica de los consumidores. Se estudia el principio de veracidad de la publicidad comercial desarrollada por los empresarios y profesionales. Se analiza el ámbito que abarca la responsabilidad civil del proveedor, en su más amplio sentido, fabricante, importador, o comerciante, es decir, empresario o profesional, como consecuencia de la vulneración de su deber de ofrecer una publicidad que se ajuste al principio de veracidad. La responsabilidad civil exigible al obligado, empresario o profesional, por incumplimiento de su obligación de veracidad publicitaria alcanza tanto la responsabilidad contractual con el consumidor que celebró el contrato, como la responsabilidad extracontractual con los consumidores que, aún sin celebrar el contrato, se han visto perjudicados por la publicidad inveraz. Se realiza una aproximación a la vinculación publicitaria en el Código civil de Nicaragua, se repasa la denominada promesa contractual, como uno de sus derivados, y algunas otras figuras clásicas, como el dolo, la buena fe y la doctrina de 
los actos propios, siempre desde la óptica de la protección jurídica de los consumidores, ya sea con las normas codificadas o con las especiales de reciente aparición.

Summary: The research paper analyzes the background of the European Community Law regarding the protection for consumers and deepens on the issue of advertisement binding in the offer made by the entrepreneur and its integration into the contract, first in the Spanish Law, with its legislative and case law background, and then in the Nicaraguan Law, particularly, within the Regulations in force related to legal protection for consumers. The truthfulness principle of the commercial advertising developed by entrepreneurs and professionals is studied. It is also analyzed the scope of civil liability of the supplier, in a wider sense, the manufacturer, the importer, or the business person, in other words, entrepreneur or professional, consequent with his duty to make an offer based on the truthfulness principle. The civil liability binding the liable, entrepreneur or professional, for not complying with his responsibility to do an advertising based on truthfulness includes not only contractual responsibility with the consumer who has celebrated the contract, but also the non - contractual responsibility with the consumers who has not celebrated a contract yet, but has been affected by the false advertising. The paper also makes an approach to the advertisement binding in the Nicaragua Civil Code, it is reviewed the contractual promise, as one of its derived and other classical precepts, such as malice, good faith, and doctrine of proper actions, starting always from the optic of legal protection for consumers either with the coded regulations or the emerging special regulations.

Palabras clave: Consumidor / consumo / contrato / publicidad / Vinculación contractual.

Key words: Consumer / consume / contract / advertising / contractual binding.

Tabla de Contenido: I. Aproximación; II. Antecedentes de Derecho comunitario europeo; III. La integración publicitaria en el vigente Derecho de consumo español; 1. Normativa española de protección del consumidor, 2. Jurisprudencia basada en las leyes de protección al consumidor, IV. Fundamento de la integración contractual publicitaria en los preceptos del Código Civil según la jurisprudencia del Tribunal Supremo español. V. La vinculación publicitaria del contrato en Nicaragua en las normas vigentes de protección jurídica de los consumidores; 1. Aproximación normativa, 2. El principio de veracidad de la publicidad comercial, 3. El derecho a exigir el contenido de la oferta y publicidad, 4. Alcance general de la responsabilidad civil del proveedor, 5. La responsabilidad del proveedor por infracción del deber de veracidad, 6. Alcance subjetivo de la vinculación de la publicidad, 7. Alcance objetivo de la vinculación publicitaria, 8. Responsabilidad civil exigible: contractual y extracontractual, VI. La vinculación 
publicitaria en el Código Civil de Nicaragua; 1. La denominada promesa contractual, 2. Eficacia e interpretación contractual, 3. La publicidad falsa o engañosa como manifestación del dolo, 4. El principio de buena fe y la doctrina de los actos propios, VII. Breve recapitulación; VII. Conclusiones. VIII Lista de Referencias.

\section{Aproximación}

La creciente influencia, en todas las ramas del Derecho, de esa pujante disciplina que venimos a denominar Derecho de protección de los consumidores y usuarios está revolucionando, en buena medida, muchos de los sólidos pilares tradicionales del vigente Derecho privado, tanto civil como mercantil, de todos los ordenamientos jurídicos del mundo; DÍEZ PICAZO se refiere a esta disciplina con las siguientes palabras:

Resulta clara la aparición al lado del tradicional Derecho de Contratos, de carácter común, de un nuevo Derecho de la Contratación, caracterizado por la consideración de una de las partes contratantes como destinatario final del bien o servicio, que determina una protección más enérgica de los intereses de tal parte contratante. (2007, p. 164).

A tal fin, en la inmensa mayoría de éstos donde se regulan los sistemas económicos de los países libres se vienen introduciendo progresivamente normas tuitivas ad hoc destinadas a proteger jurídicamente a las personas que subjetivamente, por indicarlo así la ley, ostentan la condición de «consumidor».

Tal vez sea en el ámbito de la contratación donde aquellas normas adquieran mayor eficacia práctica, al influir decisivamente en algunos de los postulados esenciales del contrato, considerados «sagrados» hasta tiempos muy recientes. Sin embargo, una inteligente actualización exegética y nueva lectura interpretativa, que tengan en cuenta el carácter dinámico de la realidad socioeconómica actual, quizá, más que derribar sus vetustas columnas, pueda servir, en el fondo, para consolidar, aún más, el bimilenario templo romano de la institución contractual, esculpido por tantas influencias canonistas y germánicas durante el Medievo, y en el último medio siglo, por la nueva cultura jurídica que se desprende de los países de la vieja Europa y de todos lo que conforman el Nuevo Mundo, esto es, América de norte a sur. 
Entre los aspectos del contrato clásico que reclaman una actual interpretación se encuentra, y es objeto de estas líneas, la redefinición de los efectos de los actos previos a la conclusión del mismo y la influencia que pudieran tener en las obligaciones de las partes, si llegara a celebrarse. En concreto, trataremos aquí de indagar si una interpretación de las normas vigentes en el Derecho de Nicaragua permite sostener con solidez la viabilidad del principio de integración publicitaria del contrato, y por ende, de la vinculación contractual de la publicidad comercial, con plenos efectos jurídicos.

Bien es verdad que, examinando los ordenamientos de los diferentes países americanos y europeos, resulta que no son muy abundantes, desde luego, las normas que reconozcan de manera expresa la aplicación de tal principio, extremo que sí ocurre, afortunadamente, en el caso del ordenamiento nicaragüense, al contrario que en tantos otros donde no se dispone de manera clara y expresa la vinculación contractual de la publicidad comercial, aunque en éstos, tampoco hay una disposición contraria a tal principio, lo que nos permite, sin duda, indagar en los posibles fundamentos legales que aconsejen, con solidez, mantener o rechazar tal postulado.

Con alguna excepción, como es el caso de DE LA CUESTA RUTE, quien fue el primero en reclamar la necesidad de otorgar a la publicidad cierta eficacia jurídica en el contrato: "Fuera de los supuestos que permitan considerar al acto de publicidad como oferta contractual, es posible, todavía plantearse su incidencia en la formación del contrato en un plano más genérico”, y añade:

Si el acto de publicidad es siempre y en todo caso una iniciativa del inter negocial, no parece que pueda desconocerse su trascendencia respecto de las manifestaciones de voluntad de propiamente forman el contrato. En el tráfico en masa, presidido por el volumen de las operaciones y su rápida liquidación, el fenómeno publicitario significa una argumentación que sustituye las singulares y aisladas que la conclusión de cada contrato comporta (1977, p. 150).

Doctrinalmente, tampoco fueron muy prolíficos los trabajos monográficos españoles sobre la vinculación contractual de la publicidad, hasta que ésta se plasmó en las normas positivas (Acedo Penco, 2007; Albiez Dohrmann, 2002; Arnau Moya, 2006; Baladrón Pazos y Martínez Pastor, 2007; Benjamín Antonio, 1997; Casas Planes, 2007; Clavería Gosálbez, 2002; Corrales García, 2000; Cuesta García, 1996; Díaz Gómez, 2008; Font Galán, 1988; Garcia Sais, 2005; 
Lasarte Álvarez, 1980; Lema Devesa, 1996; Martín García, 2004; Martínez Rodríguez, 2006; Miquel Rodríguez, 2001; Miranda Serrano, 2006; Montes Rodríguez, 1996; Pasquau Liaño, 2001; Pasquau Liaño, 1992; Reyes López, 1997; Rivero González, 2003; Sánchez del Castillo, 2007; Soler Pascual, 2007; Torres LANA, 1997)), tras ciertos antecedentes jurisprudenciales.

\section{Antecedentes de Derecho comunitario europeo}

En la Europa comunitaria, la Directiva 2006/114/CE, del Parlamento Europeo y del Consejo, de 12 de diciembre, sobre publicidad engañosa y publicidad comparativa, ha definido, recientemente, la publicidad engañosa como: «toda publicidad que, de una manera cualquiera, incluida su presentación, induce a error o puede inducir a error a las personas a las que se dirige o afecta y que, debido a su carácter engañoso, puede afectar su comportamiento económico o que, por estas razones, perjudica o es capaz de perjudicar». Además, se impone a los países comunitarios la obligación de establecer garantías frente a la publicidad engañosa, mediante procedimientos administrativos o judiciales, para reparar eficazmente los efectos negativos de esta publicidad ${ }^{1}$.

Anteriormente, la Directiva 1999/44/CE del Parlamento Europeo y del Consejo, de 25 de mayo de 1999, sobre determinados aspectos de la venta y las garantías de los bienes de consumo, aplicable a los 27 países que en la actualidad conforman la Unión Europea ${ }^{2}$, ya contenía algunos preceptos cuya importancia resulta decisiva en relación con el carácter vinculante de la publicidad dirigida a los consumidores y usuarios ${ }^{3}$.

1 Téngase en cuenta que, mediante la técnica legislativa de las directivas comunitarias, cada uno de los países miembros de la Unión Europea, que son los destinatarios de aquéllas, tienen la obligación, en el plazo que se determine en las mismas, de incorporar a su propio ordenamiento jurídico las normas que se establecen en dichos instrumentos. La Directiva de 2006 citada en el texto tiene su antecedente en la Directiva del Consejo CEE 84/450, de 10 de septiembre de 1984, en materia de publicidad engañosa, modificada por la Directiva 97/55/CE del Parlamento Europeo y del Consejo de 6 de octubre de 1997.

2 Integran en la actualidad la Unión Europea (UE), como miembros de pleno derecho, en los que todas las directivas comunitarias adquieren plena eficacia, los siguientes países: Alemania, Austria, Bélgica, Bulgaria; Chipre, Dinamarca, Eslovaquia, Eslovenia, España; Estonia, Finlandia, Francia, Grecia; Hungría, Irlanda, Italia, Letonia; Lituania, Luxemburgo, Malta, Países Bajos; Polonia, Portugal, Reino Unido, República Checa, Rumanía y Suecia.

3 Si bien es cierto que en las directivas se otorga cierta libertad a los Estados miembros en cuanto a la forma de introducir la regulación afectada, no es menos cierto que las directivas suelen contener, sobre todo en materia de protección al consumidor, un carácter de mínimos, es decir, se reconocen unos derechos al consumidor por debajo de las cuales los países no pueden legislar. Esto se hace patente, de manera particular, en el caso de esta Directiva 1999/44/CE, pues 
En un lenguaje, a nuestro juicio, muy enrevesado, dispone su artículo 2.1 de esta Directiva, acerca de la conformidad con el contrato, que «El vendedor estará obligado a entregar al consumidor un bien que sea conforme al contrato de compraventa», extremo que nada nuevo aporta pues se deriva del añejo principio general pacta sunt servanda, y que se contiene, con escasos matices, en la práctica totalidad de los Códigos civiles.

Así se refleja en el Código civil de la República de Nicaragua (CCN) dispone en su artículo 1.836 que: «Las obligaciones que nacen de los contratos tienen fuerza de ley entre las partes contratantes y deben cumplirse al tenor de los mismos», texto que, por cierto, es idéntico al vigente artículo 1.091 del Código civil español.

Sin embargo, es en el apartado 2 del tal artículo de esta Directiva donde se establece cuándo ha de entender («se presumirá») que los bienes de consumo son conformes con el contrato, lo que ocurrirá, entre otros supuestos, a tenor del epígrafe d) del precepto, cuando: «presentan la calidad y las prestaciones habituales de un bien del mismo tipo que el consumidor puede fundadamente esperar, habida cuenta de la naturaleza del bien y, en su caso, delas declaraciones públicas sobre las características concretas de los bienes hechas por el vendedor, el productor o su representante, en particular en la publicidad o el etiquetado».

Lo anterior implica que, cuando se incumpla lo indicado en el contrato, o lo ofrecido en las «declaraciones públicas» del vendedor o productor, a través de su «publicidad o etiquetado», supondrá, lo que denomina la Directiva, una «falta de conformidad» del consumidor con el producto adquirido para estableciendo ciertas garantías y responsabilidades del oferente que, precisamente, son el objeto de la regulación a través de la citada norma comunitaria.

Así se indica en el art. 3.1 intitulado "derechos del consumidor": «El vendedor responderá ante el consumidor de cualquier falta de conformidad que exista en el momento de la entrega del bien». En el resto del precepto se detalla cuáles son los derechos concretos del consumidor, y por tanto, de qué modo efectivo

su artículo 8 dispone: «Derecho interno y protección mínima 1. Los derechos conferidos por la presente Directiva se ejercerán sin perjuicio de otros derechos que pueda invocar el consumidor en virtud de otras normas nacionales relativas a la responsabilidad contractual o extracontractual. 2. Los Estados miembros podrán adoptar o mantener, en el ámbito regulado por la presente Directiva, disposiciones más exigentes, compatibles con el Tratado, para garantizar al consumidor un nivel de protección más elevado». 
ha de materializarse, y hasta dónde alcanza la responsabilidad del vendedor, y del productor en su caso, en tales supuestos de falta de conformidad del consumidor 4 .

Si el incumplimiento de «las declaraciones públicas sobre las características concretas de los bienes hechas por el vendedor, el productor o su representante, en particular en la publicidad» genera la responsabilidad de aquéllos, es evidente que el precepto está reconociendo, de manera expresa, en el ámbito de toda la Europa comunitaria, el carácter contractualmente vinculante de la publicidad comercial en cualesquiera formas que pueda manifestarse («declaraciones públicas»), lo que supone que lo exigible por el comprador no ha de ceñirse, en exclusiva, al texto de lo pactado expresamente en el contrato, si lo hubiere, como tradicionalmente se entendía.

Es cierto que, anteriormente, ya se venía aplicando en ciertos países europeos, aunque de manera desigual, tal principio, sobre todo a raíz de ciertainterpretación por los Tribunales de Justicia de determinados preceptos de los Códigos civiles que tienen su origen en el de Napoleón de 1804, tan influyente, también, en Latinoamérica.

$4 \quad$ Artículo 3 de la Directiva 1999/44/CE del Parlamento Europeo y del Consejo, de 25 de mayo de 1999, sobre determinados aspectos de la venta y las garantías de los bienes de consumo: «2. En caso de falta de conformidad, el consumidor podrá exigir que los bienes sean puestos en conformidad mediante la reparación o la sustitución del bien sin cargo alguno, de conformidad con el apartado 3, o una reducción adecuada del precio o la resolución del contrato respecto de dicho bien, de conformidad con los apartados 5 y 6. 3. En primer lugar, el consumidor podrá exigir al vendedor que repare el bien o que lo sustituya, en ambos casos sin cargo alguno, salvo que ello resulte imposible o desproporcionado. Se considerará desproporcionada toda forma de saneamiento que imponga al vendedor costes que, en comparación con la otra forma de saneamiento, no sean razonables, teniendo en cuenta: - el valor que tendría el bien si no hubiera falta de conformidad,- la relevancia de la falta de conformidad, y- si la forma de saneamiento alternativa pudiese realizarse sin inconvenientes mayores para el consumidor. Toda reparación o sustitución deberá llevarse a cabo en un plazo razonable y sin mayores inconvenientes para el consumidor, habida cuenta de la naturaleza de los bienes y de la finalidad que tuvieran los bienes para el consumidor. 4. La expresión "sin cargo alguno" utilizada en los apartados 2 y 3 se refiere a los gastos necesarios realizados para subsanar la falta de conformidad de los bienes con el contrato, especialmente los gastos de envío, así como los costes relacionados con la mano de obra y los materiales. 5. El consumidor tendrá derecho a una reducción adecuada del precio o a la resolución del contrato: - si no puede exigir ni la reparación ni la sustitución, o - si el vendedor no hubiera llevado a cabo el saneamiento en un plazo razonable, o- si el vendedor no hubiera llevado a cabo el saneamiento sin mayores inconvenientes para el consumidor. 6. El consumidor no tendrá derecho a resolver el contrato si la falta de conformidad es de escasa importancia». 
Sin embargo, el reconocimiento claro y expreso, a través del derecho positivo, de la vinculación contractual de la publicidad comercial en los contratos celebrados con consumidores, o en otros términos, de la integración publicitaria del contrato, supone, a nuestro juicio, un «revolucionario» avance en materia de Derecho privado del que, más pronto que tarde, ninguno de los países tributarios del Código civil francés podrá sustraerse en ninguno de los dos lados del Atlántico.

\section{La integración publicitaria en el vigente Derecho de consumo español}

\section{Normativa española de protección del consumidor}

En principio, la aplicación en España del principio de la integración publicitaria de los contratos celebrados con consumidores no habría de distinguirse demasiado del resto de los países de la Unión Europea, por lo que, tomando como base la Directiva 1999/44/CE apuntada, el resultado habría de ser similar, ya su contenido se encuentra transpuesto en el Real Decreto Legislativo 1/2007, de 16 de noviembre, por el que se aprueba el texto refundido de la Ley General para la Defensa de los Consumidores y Usuarios (TRLCU)5.

Sin embargo, más específico aún, si cabe, es el vigente artículo 61 del TRLCU sobre "Integración de la oferta, promoción y publicidad en el contrato", cuyo apartado 2 determina, con mucha mayor precisión que: «El contenido de la oferta, promoción o publicidad, las prestaciones propias de cada bien o servicio, las condiciones jurídicas o económicas y garantías ofrecidas serán exigibles por los consumidores y usuarios, aún cuando no figuren expresamente en el contrato celebrado o en el documento o comprobante recibido y deberán tenerse en cuenta en la determinación del principio de conformidad con el contrato» ${ }^{6}$.

$5 \quad$ El artículo 116 del TRLCU sobre "Conformidad de los productos con el contrato" reproduce, prácticamente con idéntico texto, el artículo 3 de la Directiva 1999/44/CE transcrito anteriormente

Pese a referirse el precepto a «la oferta, promoción o publicidad», en realidad, no parece muy exacta la inclusión de la «oferta», ya que, desde un punto de vista técnico, cuando la oferta es aceptada la declaración de voluntad que contiene ya es parte integrante del contrato. Y la «promoción» puede entenderse como una forma de publicidad, dado su carácter público, por tanto, pese a la utilización de los tres términos lo correcto, y a lo que el precepto se refiere, es, a la «publicidad» comercial de bienes y servicios en cualesquiera de sus modalidades que se dirijan a promover su comercialización. 
Previamente, el apartado 1 indica que: «La oferta, promoción y publicidad de los bienes o servicios se ajustarán a su naturaleza, características, utilidad o finalidad y a las condiciones jurídicas o económicas de la contratación». Es decir, está sentando, con carácter imperativo, el principio de veracidad en la publicidad comercial, en el sentido más amplio. Y concluye el mismo art. 61 con su apartado 3 donde, además de lo anterior, establece un precepto residual de gran interés, al primar el contenido del contrato en el caso de que sea más beneficioso que la propia publicidad comercial, la promoción o la oferta al consumidor: "No obstante lo dispuesto en el apartado anterior, si el contrato celebrado contuviese cláusulas más beneficiosas, estas prevalecerán sobre el contenido de la oferta, promoción o publicidad».

El citado precepto no tiene su antecedente en la Directiva 1999/44/CE, ni en ninguna otra normativa comunitaria, sino en la derogada Ley española de protección de los consumidores de 1984, que, casi tres lustros antes que la norma europea, ya reconocía expresamente el principio de la vinculación publicitaria e integración del contrato celebrado con consumidores7.

La modificación sustancial, mediante el art. 61 TRLCU, del régimen tradicional de las obligaciones y responsabilidades de los contratantes, tal vez sea una consecuencia más del mandato de protección a los consumidores y usuarios que se impone en el art. 51 de la Constitución española de $1978^{8}$, cuya base teórica se anuncia en el art. $1.1 \mathrm{del}$ mismo texto constitucional, al configurar el Estado de Derecho con la cualidad de "social", que exige una conducta activa y de cierta intervención económica por parte de los poderes públicos en defensa de los sectores más débiles de la Sociedad.

Los efectos contractuales de aquellas normas sobre la integración publicitaria del contrato celebrado con los consumidores, y su consiguiente

$7 \quad$ Artículo 8.1 de la Ley 26/1984, de 19 de julio, General para la Defensa de los Consumidores y Usuarios, derogada por el Real Decreto Legislativo 1/2007, de 16 de noviembre, cuyo contenido se reproduce, casi literalmente, en el vigente artículo 61.2 de éste, cuya transcripción consta en el texto.

8 Artículo 51 de la Constitución española: «1. Los poderes públicos garantizarán la defensa de los consumidores y usuarios, protegiendo, mediante procedimientos eficaces, la seguridad, la salud y los legítimos intereses económicos de los mismos. 2. Los poderes públicos promoverán la información y la educación de los consumidores y usuarios, fomentarán sus organizaciones y oirán a éstas en las cuestiones que puedan afectar a aquéllos, en los términos que la ley establezca. 3. En el marco de lo dispuesto por los apartados anteriores, la ley regulará el comercio interior y el régimen de autorización de productos comerciales». 
vinculación, son de extraordinario alcance práctico para el consumidor, ya que implican lo siguiente (AcEDo Penco, 2003):

a) Se legitima al consumidor para exigir al empresario todas las prestaciones propias de cada producto ofrecido, según la naturaleza del mismo, estén o no plasmadas en el contrato escrito, o en el instrumento confeccionado al efecto.

b) La norma autoriza al consumidor para reclamar todo lo que, de manera lo que se denomina, técnicamente, la integración del contrato. El principio básico de la integración contractual publicitaria implica, además, concretar la aplicación de determinadas normas, de origen diverso, que globalmente regulan un contrato.

No sólo serán parte del contrato las normas civiles y mercantiles en materia de oferta y publicidad que sean aplicables al caso, sino que además, todas aquellas características, ventajas, cualidades, propiedades o atributos de los bienes y servicios que se hayan ofrecido en el mensaje publicitario, y que seguramente habrán servido de reclamo para atraer al consumidor, quedarán plenamente integradas en el contrato que celebre y se convertirán en cláusulas vinculantes para el empresario, aunque no figuren de manera expresa en el mismo. Se trata, en definitiva, en este apartado, de la integración publicitaria por omisión en el contrato, sin importar la forma en que se hubiere plasmado.

Sin embargo, ha de advertirse que algún sector doctrinal, sin llegar a negarlo de manera expresa, ha matizado, restrictivamente, el alcance de este carácter vinculante de la publicidad comercial o exigibilidad de las declaraciones públicas en ella contenidas, considerando, desde dicha optica, que «la publicidad comercial es un criterio de interpretación de la declaración contractual»9.

9 (PASQUAU LIAÑO, 1992, P. 164) tras afirmar la frase entrecomillada en el texto, añade que el problema de la exigibilidad y de la integración del contrato ha de tratarse bajo las siguientes hipótesis: $1^{\circ}$.- La publicidad sólo es exigible en el caso de laguna del contrato. $2^{\circ}$.- La medida establecida en el art. 8 (actual art. 61 TRLCU), es una sanción de la publicidad engañosa y sólo es aplicable en aquellos casos en los que tal engaño se produzca por dolo o negligencia. $3^{\circ}$.- Tal medida se refiere a la publicidad objetivamente falsa, pero no a todo supuesto de publicidad que induzca a error. $4^{\circ}$.Para que sea exigible el contenido publicitario es preciso que el consumidor haya sido inducido por la publicidad engañosa para celebrar el contrato. $5^{\circ}$. Los límites de la exigibilidad de la publicidad son los mismos que los de todos los demás derechos subjetivos. Tales hipótesis son examinadas, de manera crítica, por (DÍEZ-PICAZO, 2007). 
También se ha defendido doctrinalmente, con solidez, que la vinculación contractual de la publicidad no tiene como función castigar de manera especial a la publicidad comercial inveraz, sino que su función es proteger la confianza del consumidor, es decir, lo que éste puede esperar de los bienes y servicios como consecuencia de las declaraciones públicas que sobre el mismo se han realizado ${ }^{10}$.

c) Se reconoce además al consumidor una cláusula o contenido prestacional más beneficioso para él, disponiéndose en ella la integración contractual publicitaria por contradicción o divergencia con el contenido del contrato. Las cláusulas del contrato o las prestaciones ofrecidas mediante la publicidad que resulte más favorables para los consumidores serán siempre exigibles: tanto si figuran expresamente o no en el contrato, como si figuran en éste, pero con alteraciones o divergencias respecto al contenido publicitario.

Ello implica que el contrato se integra publicitariamente en beneficio del consumidor, es decir, que no procederá dicha integración publicitaria del contrato si de ella no se deriva un beneficio neto para el consumidor. La consecuencia lógica de lo anterior es que el empresario anunciante que ha predispuesto el contenido formal del contrato no podrá valerse de la integración para mejorar su posición en perjuicio del consumidor, antes al contrario, éste será quien pueda beneficiarse.

\section{Jurisprudencia basada en las leyes de protección al consumidor}

El Tribunal Supremo español aplica la doctrina expuesta más arriba establecida inicialmente en el artículo 8 de la Ley 26/1984, de 19 de julio, General para la Defensa de los Consumidores y Usuarios, aunque también, sigue acudiendo a los preceptos del Código civil para reforzar los efectos jurídicos que atribuye a la integración publicitaria del contrato. Pueden señalarse, a efectos ilustrativos, tan sólo tres pronunciamientos jurisprudenciales del Alto Tribunal:

La Sentencia del Tribunal Supremo (STS) de España de 7 noviembre de 1988 indica que: «la publicidad sobre un objeto, sobre todo si es un objeto aún no existente, forma parte esencial de la oferta, como se reconoce por la doctrina y

10 (Morales Moreno, 1999) distingue entre publicidad de carácter informativo y publicidad de reclamo, considerando sólo a la primera como fuente de integración contractual. 
ha venido a proclamar el art. 8 de la Ley 26/1984, general para la defensa de los Consumidores y Usuarios, y origina responsabilidad en el oferente».

En la STS de 20 de enero de 1989 se toma en cuenta la descripción de calidades que el promotor-constructor hizo en los anuncios publicitarios y afirma que ello "permite al juzgador concluir de una parte, en la decisiva influencia de la publicidad» sobre la conducta y voluntad de los actores al contratar y, de otra, en la existencia de defectos y omisión de detalles en la obra entregada, respecto de lo ofrecido públicamente y contemplado en las memorias descriptivas y contratos correspondientes.

Y, finalmente, la STS de 21 de julio de 1993 señala la «obligación exclusiva de la promotora a finalizar la obra de modo que reúna las características constructivas ofrecidas públicamente a los futuros compradores, conforme a lo establecido en los arts. 1096, 1101, 1256 y 1258 del CC y art. 8 de la Ley General para la Defensa de los Consumidores y Usuarios», de 1984.

\section{Fundamento de la integración contractual publicitaria en los preceptos del Código civil según la jurisprudencia del Tribunal Supremo español}

Pero incluso varios años antes de que entrara en vigor la primera Ley de protección al consumidor en España, en 1984, ya la Sala de lo Civil del Tribunal Supremo dictó dos sentencias una en 1976 y otra en $1977^{11}$, cuyo audaz planteamiento puede calificarse de revolucionario, ya que los citados pronunciamientos jurisprudenciales supusieron un giro copernicano en la línea interpretativa tradicional que venía considerando irrelevante a efectos contractuales la publicidad comercial de carácter engañoso o falaz tan sólo como un supuesto típico del llamado dolus bonus, desde luego insuficiente para viciar el consentimiento contractual y para atacar la plena validez del contrato.

Téngase en cuenta, a los efectos de la vinculación publicitaria que, en las sentencias que se citan se aplican los artículos 7, 1096, 1101, 1256, 1258, 1282 y 1283 del Código civil español, cuyo texto es, similar, y en algunos casos idéntico,

11 STS de 14 de junio de 1976 y STS de 27 de enero de 1977. En ambas sentencias fue ponente el magistrado Antonio Cantos Guerrero, y fueron el antecedente jurisprudencial del artículo 8 de la citada Ley 26/1984, de 19 de julio, ya derogada, pero cuyo contenido fue recientemente «refundido» y por tanto, hoy plenamente vigente, en el artículo 61 del Real Decreto Legislativo 1/2007, de 16 de noviembre (TRLCU) actual Ley de consumidores española. 
a sus homólogos del Código civil de la República de Nicaragua, por lo que, tal vez, la siguiente doctrina jurisprudencial pueda ser de alguna utilidad para el operador y el intérprete del Derecho civil nicaragüense.

La que nos hemos atrevido a denominar «revolucionaria» doctrina sobre la vinculación contractual de la publicidad, fue recogida en España casi una década antes de su reconocimiento legal expreso, básicamente, en las siguientes sentencias de la Sala Primera, de lo Civil, del Tribunal Supremo (STS):

a) Fue pionera la STS de 14 de junio de 1976, que fundamenta la condena al vendedor de una determinada maquinaria en que: «no da el rendimiento que se anunciaba en la propaganda fotográfica y gráfica unida a los autos que cumple la función de una oferta que vincula al vendedor, en la que se afirmaba un rendimiento horario, oferta por la que se guió el comprador», añadiendo que éste «se atuvo exclusivamente, como ocurre siempre en estos casos, a los datos consignados públicamente en la oferta, sin duda con ánimo de captación a través de la propaganda; oferta que no ha sido cumplida» ${ }^{12}$.

b) La STS de 27 de enero de 1977, fundamentándose en el principio de la buena fe que transgrede una de las partes del contrato, condena a la empresa vendedora, en este caso de una vivienda, obligándole a instalar un sistema de aire acondicionado y a realizar las obras precisas para lograr la adecuada insonorización de tal vivienda, ya que tales elementos aparecían como propios de la vivienda en los folletos publicitarios que fueron distribuidos por la vendedora, y que sirvieron para atraer al consumidor y comprar el piso en cuestión ${ }^{13}$.

c) La STS de 5 de enero de 1980, basándose también en la infracción del principio de buena fe, reconocido en los artículos 7 y 1.258 del Código

12 La STS de 14 de junio de 1976 condenó a una empresa a retirar a su costa de manos de su cliente y comprador una determinada maquinaria industrial para la fabricación de harina de pescado, y a enviar a tal comprador otra máquina que se correspondiera, en sus características técnicas y rendimiento industrial, al tipo de maquinaria anunciada en los folletos publicitarios emitidos por el vendedor y que sirvieron de guía y base al comprador para celebrar el contrato. En concreto la publicidad gráfica de los folletos se afirmaba un rendimiento de 2.000 a 3.000 litros cada hora, demostrándose luego en los autos que la producción de la máquina no alcanzaba tales cifras por lo que la sentencia estimó que el vendedor había incumplido el contrato.

13 La STS de 27 de enero de 1977 desestima los argumentos de la empresa quien afirma que «un folleto de publicidad no es un contrato», ya que el adquirente confía en la buena fe del vendedor y además los planos de construcción contienen lo ofertado en aquella publicidad. 
civil, condenó a la empresa vendedora de un chalet, que se anunció como provisto de maravillosas vistas al mar, a la reducción del precio establecido en el contrato de compraventa, a causa de la posterior construcción por el mismo vendedor y demandado, de otras viviendas delante del chalet que eliminaron las vistas panorámicas, al haberse probado las aseveraciones del vendedor al comprador de que siempre conservaría aquellas vistas pues nunca construiría en el terreno delantero de tal chalet ${ }^{14}$. Se completa con la STS de 16 de noviembre de 1979 sobre la interpretación procesal de la buena $\mathrm{fe}^{15}$.

d) En la STS de 9 de febrero de 1981 se condena a una empresa constructora de una urbanización de viviendas obligándola a ceder a los compradores de los pisos las zonas deportivas y recreativas, al entender que la intención de las partes contratantes debía ser interpretada -e integrada- de acuerdo con las declaraciones publicitarias, de las que se deducía la inclusión de tales elementos como zonas comunes de la urbanización ${ }^{16}$.

$14 \quad$ La STS de 5 de enero de 1980 contiene estos interesantes argumentos: «y, de otra parte, debido a que esa reducción de precio es ineludible consecuencia de la situación de buena fe contractual derivada de una recíproca confianza, derivada de la expresada fijación de un mayor precio con base en la efectividad de la tan citada obligación asumida y no acreditada como cumplida hasta ahora por el tan aludido vendedor, productor de una justa equivalencia en las respectivas prestaciones, porque la normativa contenida explícitamente en el art. 1258 del Código Civil y genéricamente en el art. $7^{\circ}$ del propio Cuerpo legal sustantivo, en cuanto reconocen que los derechos deberán ejercitarse conforme a las exigencias de la buena fe, determina que en todo negocio jurídico lo esencial a tener en cuenta, en orden a sus efectos, sea conocer la voluntad de los en él intervinientes, con el fin de autenticar cuál fuere la inspiración y propósito a que responde, como para decidir sus consecuencias en derecho, función de la llamada interpretación, que lo mismo puede versar sobre el texto o convenciones escritas o verbales, en que la voluntad se hubiese exteriorizado, que respecto al comportamiento contractual, y más en cuanto afecta al fin económico, que tiene tan constante aplicación y trascendencia en la esfera del derecho privado y que frecuentemente ilumina con potente luz la conducta de las personas en sus relaciones de índole jurídica».

15 Precisa la STS de 16 noviembre 1979 que, en virtud de la regla de derecho procesal da mihi factum, ego dabo tibi ius, en toda relación jurídica, como revelación objetiva que es la esencial indagadora de la voluntad reflejada en el consentimiento, lo fundamental que hay que proteger es la confianza, ya que el no hacerlo es atacar a la buena fe, que ciertamente se basa en una coherencia de comportamiento en las relaciones humanas y negociales, dado que cuando unas determinadas personas, dentro de un convenio jurídico, han suscitado con su conducta contractual una confianza mutua fundada, conforme a la buena fe, en una determinada situación, no debe defraudar esa confianza suscitada».

16 Afirma la STS de 9 de febrero de 1981 que: «los contratos de que se viene haciendo examen comprenden no estrictamente los pisos y chalets vendidos comprendidos en la urbanización nominada «Residencial San José», sí que también alcanzan a la zona deportiva, y concretamente a la piscina a ella adscrita, produce como lógica consecuencia que la Sala sentenciadora de instancia, en contra de lo apreciado por el tan meritado recurrente, realizó la deducción interpretativa de los relacionados actos anteriores, coetáneos y posteriores que conduce a acoger en las referidas enajenaciones la indicada zona deportiva, y en su consecuencia la expresada piscina, derivado de los hechos demostrados por el aspecto de que la pública oferta de venta lo 
e) La STS de 8 de noviembre de 1996, hace un repaso a la doctrina dela vinculación contractual de la oferta y la publicidad, incluyendo tanto la que apoya en las normas de protección de los consumidores como en preceptos generales sobre obligaciones y contratos, afirmando que, en el caso enjuiciado: «no se podía prescindir de los treinta y cinco folletos de propaganda aportados a los autos; y al tenerlos en cuenta, su valoración de la prueba se muestra, cuando menos, ilógica, ya que se trata de documentos que contienen actividad publicitaria, con intención de atraer a los clientes, constituyendo una clara oferta, de forma que al no entenderlo así se infringen los arts. 57 del Código de Comercio el principio de la buena fe y el art. 1283 del Código civil», a lo que se añade: «debiendo tal publicidad integrar los contratos, pues para que no fuese así tenía que excluirse expresamente de los mismos el contenido de los folletos, sin que para tal consideración fuere necesario apreciar engaño o fraude ${ }^{17}$.

f) La STS de 23 de mayo de 2003 enjuiciaba un supuesto en el que una promotora ofrecía mediante folletos de publicidad la venta de viviendas con tres pistas de tenis que iban incluidas en la urbanización y que pasarían a la comunidad de los propietarios adquirientes, extremo que también se especificaba en el proyecto de obras, pero no en la escritura final donde la promotora no incluyó una de las tres pistas de tenis, sino que la vendió aparte a una empresa que tenía estrecha relación con el administrador único de aquella promotora. Se ejercitó por los compradores la acción para incluir esta tercera pista dentro de la comunidad, tal como indicaba la publicidad, pretensión que fue estimada y confirmada por el Tribunal Supremo, en base a las normas de protección de los consumidores, que, según la misma, responde a los principios clásicos del Derecho como son el «principio de veracidad de la publicidad» y el «principio de la buena fe», en virtud de los cuales se establece una forma de complementar o integrar el contrato con aquello en que el consumidor

comprendía, conducente al enlace preciso y directo según las reglas del criterio humano, dado que lo que sirvió de público y general ofrecimiento indudablemente, y en tanto no se excluya expresamente, es comprendido en lo contratado con base a esa oferta, y por tanto en manera alguna supone interpretación errónea del art. 1253 en relación con el 1283, ambos del CC, en cuanto éste sanciona «que no deberán entenderse comprendidos en el contrato cosas distintas y casos diferentes de aquéllos sobre los que los interesados se propusieron contratar», sino, por el contrario, riguroso acatamiento a esa normativa, dado que precisamente lo que hace la resolución impugnada es comprender en los contratos tan citados lo que a medio de ellos se propuso fuese su objeto como consecuencia de lo propuesto contratar». protección de los consumidores y sobre la publicidad comercial, y en la STS de 22 de julio de 1994. Esta postura se ratifica luego en la STS de 30 de junio de 1997. 
ha confiado por razón de la oferta, promoción y publicidad, apoyándose, además, en este caso, en la «doctrina de los actos propios» (nemo potest contra proprium actum venire ${ }^{18}$.

g) En el mismo sentido, se aplican los anteriores criterios, convertidos ya en principios normativos aplicados ya sin discusión por la jurisprudencia del Alto Tribunal español, entre otras, en las posteriores STS de 29 de septiembre de 2004, la STS de 5 de abril de 2006 y la STS de 5 de abril de $2006^{19}$.

Como antes se expresó, la oportunidad de exponer estos antecedentes jurisprudenciales, ajenos Nicaragua, como es el caso de España, se justifica en muchos de los fundamentos que se despliegan en tales sentencias, ya que, algunas, se basan en las modernas normas de protección al consumidor, pero otras, la mayoría de las citadas, elaboran una doctrina a partir del Derecho privado tradicional, ya centenario contenido en el Código civil español de 1889, lo que puede llegar a gozar de una extraordinaria utilidad práctica para el jurista nicaragüense, ya que muchas de las normas de aquel viejo cuerpo normativo allende el Atlántico, son idénticas, o muy similares, a las del Código civil de la República de Nicaragua.

18 Expresa la STS de 23 de mayo de 2003 que «el principio general de derecho que veda ir contra los propios actos (nemo potest contra proprium actum venire), como límite al ejercicio de un derecho subjetivo o de una facultad, cuyo apoyo legal se encuentra en el art. 7.1 del Código Civil que acoge la exigencia de la buena fe en el comportamiento jurídico, y con base en el que se impone un deber de coherencia en el tráfico sin que sea dable defraudar la confianza que fundadamente se crea en los demás, precisa para su aplicación la observancia de un comportamiento (hechos, actos) con plena conciencia de crear, definir, fijar, modificar, extinguir o esclarecer una determinada situación jurídica, para lo cual es insoslayable el carácter concluyente e indubitado, con plena significación inequívoca, del mismo, de tal modo que entre la conducta anterior y la pretensión actual exista una incompatibilidad o contradicción, en el sentido que, de buena fe, hubiera de atribuirse a la conducta anterior».

19 La doctrina de estas dos últimas sentencias se aplica en un caso, más habitual de lo deseable, con el siguiente argumento: «se han frustrado las expectativas del comprador, ya que si se compra una vivienda como teniendo vistas al mar, libres y directas y luego resulta que no las tiene, es evidente la disminución de valor, tanto económica como de utilidad, de la vivienda que se adquiere, según la publicidad del promotor, en "primerísima línea de playa", y "con vistas al mar", dándose a entender en la promoción publicitaria la existencia de una vista directa y total sobre el mar en primera línea de edificaciones, no oblicuas y obstaculizadas por ninguna construcción, resulta evidente que, el incumplimiento y la incapacidad de entrega en tales condiciones, libremente asumidas por la vendedora, priva sustancialmente al consumidor comprador de lo que tenía derecho a esperar en virtud del contrato». 


\section{La vinculación publicitaria del contrato en Nicaragua en las normas vigentes de protección jurídica de los consumidores}

\section{Aproximación normativa}

Una rápida lectura de la Ley de Defensa de los Consumidores de la República de Nicaragua (Ley núm. 182, aprobada el 22 de septiembre de 1994) nos hace ver que, entre los derechos que se reconocen a los consumidores en su artículo 12, se contiene, además del derecho, en su apartado c), a «una información veraz, oportuna, clara y adecuada sobre los bienes y servicios disponibles en el mercado», también, el derecho a «exigir el cumplimiento de las promociones y ofertas cuando el proveedor no cumpla».

El texto anterior nos lleva, sin demasiados obstáculos, a sostener la vigencia y aplicación de la doctrina de la vinculación contractual de la publicidad de de los contratos celebrados con consumidores en la República de Nicaragua, ya desde 1994, un lustro antes de que fuera reconocida en la Directiva europea antes examinada, situación que parece afianzarse en el futuro según el texto del Proyecto de Ley de Protección a los Derechos de los Consumidores y Usuarios ${ }^{20}$.

\section{El principio de veracidad de la publicidad comercial}

El principio de veracidad de la información y publicidad se reconoce, aunque de manera parcial, e incluso, tal vez, insuficiente, en el artículo 13 de la Ley 182, al indicar que «Todo proveedor de bienes brindará al consumidor información clara, veraz y suficiente al menos sobre las siguientes características: a) Composición, Finalidad y aditivos utilizados; b) Cantidad de productos. c) Fecha de producción y vencimiento del producto. d) Instrucciones e indicación para su uso. e) Advertencias, riesgos e incompatibilidad con otros productos».

La dicción del precepto pudiera confundir al apresurado lector ya que, en un sentido literal, esa «información clara, veraz y suficiente» sólo se predica, de manera específica, para los cinco apartados que luego enumera, por lo que,

20 Según el Dictamen de 18 de octubre de 2006 de la Comisión de Producción, Distribución y Consumo de la Asamblea Nacional de la República de Nicaragua sobre el «Proyecto de Ley de Protección a los Derechos de los Consumidores y Usuarios» remitido a dicha Comisión el 7 de marzo de 2007, cuyo objeto es «subsanar debilidades e inconsistencias jurídicas, originadas por el desfase de cinco años transcurridos desde la aprobación de la Ley». 
a sensu contrario, en todo lo que no aparezca en ellos no sería preciso que cumplieran tal condición.

Sin embargo, a nuestro entender, no es tal la interpretación que haya de darse al precepto, puesto que, habrá que convenir que el artículo 13 contiene un plus específico de veracidad en la información y publicidad respecto de los apartados que se desarrollan en el mismo, pero sin que ello deba suponer, ni mucho menos, que no deba cumplirse tal principio en el resto de aspectos no contenidos en tales apartados.

Ello ha de ser así, naturalmente, por cuanto dicho principio, aunque con un carácter más general, pero en absoluto excluyente, ya queda enunciado en el citado artículo 12 apartado c) de la Ley 182, cuando reconoce al consumidor el derecho a «una información veraz, oportuna, clara y adecuada sobre los bienes y servicios disponibles en el mercado».

No obstante lo anterior, también el artículo 20 de la Ley vuelve a apuntalar el principio de veracidad publicitaria, aunque ahora la reserve para las que denomina «promociones y ofertas», pues se exigen a éstas la máxima claridad en sus aspectos esenciales, como el plazo de duración, la calidad de lo que sea objeto, así como los bienes o productos ofrecidos y el desglose de todo lo que se ofrezca como premio.

\section{El derecho a exigir el contenido de la oferta y publicidad}

Se reconoce expresamente, en el apartado f) del artículo 12 de la Ley 182 de Nicaragua, el derecho a «exigir el cumplimiento de las promociones y ofertas cuando el proveedor no cumpla». No cabe duda que la publicidad comercial está integrada por las «promociones y ofertas» que realiza el proveedor, pues en ambos casos se trata de una información de carácter precontractual que el precepto autoriza a exigir.

Bajo el título "Responsabilidad civil", el capítulo VII de la Ley nicaragüense contiene un solo artículo, el 27, cuyo tenor dispone: «El proveedor incurre en responsabilidad civil en los siguientes casos: a) Venta de bienes y servicios atribuyéndoles características o cualidades distintas de las que realmente tiene; b) Falta de cumplimiento con las condiciones de la oferta, promoción o propaganda. c) Venta de bienes usados o reconstruidos, como si fueran nuevos; d) Promoción de bienes y servicios con base a declaraciones falsas, 
concernientes a desventajas o riesgos de la competencia; e) Ofrecer garantías sin estar en capacidad de darlas.

La responsabilidad en la que incurre en vendedor, según el precepto, se deriva, en síntesis, del incumplimiento del principio de veracidad en las diferentes posibilidades que esta norma determina, esto es, cuando se falsean sus características o cualidades y cuando se incumple lo que se declaró en la oferta, la promoción o la publicidad de los bienes y servicios.

\section{Alcance general de la responsabilidad civil del proveedor}

Pese al título del capítulo anterior (el VII), no se determina en el único artículo que lo integra el alcance de aquella responsabilidad civil del proveedor, extremo que, aparentemente, se lleva al capítulo VIII "Del procedimiento" (artículos 28 al 35), de la Ley, ya que en el mismo se contienen disposiciones sobre tal alcance.

Sin embargo, como tantas veces ocurre, pese a la claridad del artículo 27, donde se determinan con claridad los supuestos en los que el proveedor incurre en responsabilidad civil, básicamente por incumplir el principio de veracidad en la oferta y en la publicidad comercial, no se establece, de manera especial, ninguna consecuencia expresa para tales casos.

Es decir, parece que el legislador ha dispuesto unos perfectos supuestos de hecho en el artículo 27 de la ley, pero luego se ha olvidado de atribuirle, de forma expresa, consecuencia jurídica alguna a tan impecables supuestos. Y es que, examinando la Ley, dos preceptos determinan el alcance de la responsabilidad del productor:

a) El artículo 28, que sólo concede al consumidor el derecho de opción, de «pedir la rescisión» el contrato o la reducción del precio, sin perjuicio de la indemnización por daños y perjuicios», pero sólo y exclusivamente, en aquellos casos en los que «la cosa u objeto del contrato tenga defectos o vicios ocultos que la hagan impropia o disminuyan su calidad o su posibilidad de uso al que normalmente se destina; y que de haberlos conocido el consumidor este no los hubiere adquirido».

b) Y el artículo 30, que reconoce al consumidor el «derecho de reposición del producto o en su caso la devolución de la suma pagada», pero sólo en dos supuestos: $1^{\mathrm{o}}$.- cuando aquél haya recibió un producto de inferior calidad o 
cantidad, o ambas, a las que debería tener, o a las indicadas en el envase o paquete; y $2^{\circ}$.- cuando el producto «se encontrare en mal estado».

O sea, que, extrañamente, si bien se establecen consecuencias jurídicas para los supuestos en que lo adquirido por el consumidor tuviere vicios o defectos de cantidad o de calidad, sin embargo, nada se prevé en la Ley para los supuestos enumerados en el artículo 27, en especial en lo referente a su apartado b) ${ }^{21}$, con el agravante de la vigencia del viejo aforismo latino ubi lex non distinguit nec nos distinguere debemus.

\section{La responsabilidad del proveedor por infracción del deber de veracidad}

La omisión legal de cualquier referencia a los derechos que hayan de concederse al consumidor en caso de que el proveedor incumpla el principio de veracidad en la oferta y publicidad comercial, cuya responsabilidad civil se reconoce expresamente en el artículo 27.b) de la Ley 182, no puede conducir a la fatal consecuencia de quedar dicho precepto vacío de todo contenido o derecho para el consumidor.

El Reglamento de la Ley 182, "Ley de defensa de los consumidores", aprobado el 12 de mayo de 1999 por la Asamblea Nacional de la República de Nicaragua, mediante el Decreto 2187,limitándose a repetir lo dispuesto en el texto legal ${ }^{22}$ reconoce a los consumidores, en el apartado c) de su artículo 3, el derecho a «recibir información veraz, oportuna, clara y adecuada sobre los bienes y servicios disponibles en el mercado»; en el apartado e), el derecho a «demandar una reparación integral, oportuna y adecuada de los daños y perjuicios sufridos que sean responsabilidad del proveedor», y finalmente, en el apartado f) «exigir el cumplimiento de las promociones y ofertas cuando el proveedor no cumpla».

Siendo lo anterior, como se ha dicho, una mera reproducción legal, sin embargo, este Decreto 2187 se separa de la Ley que desarrolla, completándola, al precisar, en su artículo 58 que: «Los fabricantes, importadores, distribuidores y expendedores en general de cualquier producto o servicio están en la obligación de cumplir lo ofertado en el tiempo y en los términos anunciados en la publicidad».

21 «Falta de cumplimiento con las condiciones de la oferta, promoción o propaganda».

22 Artículo 12 de la Ley 182, apartados c), e) y f). 
Tal precepto, por fin, establecería la natural consecuencia jurídica al supuesto de hecho contemplado en el artículo 27.c) de la Ley 182, ya que, de una manera clara, se desprende que el consumidor puede exigir que el vendedor, y los demás empresarios o profesionales, cumplan lo ofertado «en los términos anunciados en la publicidad».

Pero un obstáculo se opone a tal efecto jurídico, y es que, dada la ubicación del «valioso" artículo 58 del Reglamento, dentro del capítulo IX "Del derecho a exigir el cumplimiento de las promociones", parece que tal precepto se refiere tan solo a lo referido en dicho capítulo, esto es, a lo que en el mismo denomina como "promociones». Ello se agrava al advertir que los conceptos de «oferta» $\mathrm{y}$ «de publicidad comercial» no encajan, con facilidad, en ninguno de los cinco apartados del artículo 55 en los que se determinan cuáles son las "formas de promoción" derivadas de las "prácticas comerciales consistentes en el ofrecimiento público» detalladas en los citados apartados ${ }^{23}$.

Habrá de ser el capítulo XIV del Reglamento de 1999, y en especial su artículo 95, de excelente factura, ahora sí, el que resuelva, de manera preclara, la controversia normativa que se examina, pues su tenor literal no alberga ninguna duda: «Toda información, publicidad u oferta al público, transmitida por cualquier medio o forma de comunicación, en relación con los bienes ofrecidos o servicios a prestar, vincula al proveedor que solicite, autorice o pague la difusión correspondiente. Dicha información formará parte del contrato de venta que se celebre entre el proveedor y el consumidor».

\section{Alcance subjetivo de la vinculación de la publicidad}

Ahora bien, sentado lo anterior, esto es, que el consumidor puede exigir el contenido de todo aquello que se ofrezca a través de la publicidad comercial, integrándola en el contrato o en la relación de consumo, resta por averiguar, qué personas, físicas o jurídicas, empresarios, comerciantes, o profesionales,

23 Artículo 55 del Decreto 2187: «Son formas de promoción las siguientes prácticas comerciales consistentes en el ofrecimiento al público de: a) Proporcionar adicionalmente otro bien o servicio de cualquier clase que fuere a un precio menor del habitual en el comercio o en el mismo establecimiento; o en forma gratuita. b) Bienes con un contenido adicional al de la presentación usual del producto, en forma gratuita o a un precio menor del habitual. c) Prometer dos o más bienes o servicios por un mismo precio, d) Bienes o servicios con el incentivo de participar en sorteos, rifas, concursos y otros de la misma naturaleza. e) Figuras o leyendas impresas en las cajas o envases de los productos o incluidas dentro de aquellos, distintas a las que usualmente deben llevar; sean o no coleccionables». 
habrán de hacer frente a la responsabilidad civil, contractual o no, la publicidad incumplida.

Desde el punto de vista subjetivo, el artículo 95 del Reglamento responsabiliza civilmente, en lo que aquí respecta, «al proveedor que solicite, autorice o pague la difusión correspondiente». Es decir, será el sujeto que informe, ofrezca o publicite un producto el que quedará vinculado, y por tanto, a quien podrá exigirse el cumplimiento de lo informado, ofertado o publicitado.

Ello supone la exoneración, las más de las veces, del vendedor final del producto al consumidor, ya que habitualmente no será quien lo anuncie, sobre todo en las grandes campañas publicitarias en las que será el fabricante, el importador o el distribuidor de los productos, quien «solicite, autorice o pague» aquella difusión.

No obstante, el precepto incluye como responsable civil, al que también podrá reclamarse el cumplimiento de todo lo difundido, al vendedor final, y al profesional de los servicios, cuando sean éstos quienes, directamente, ofrezcan, informen o publiciten sus productos.

\section{Alcance objetivo de la vinculación publicitaria}

No se establece limitación alguna, en el artículo 95 del Decreto 2187, acerca de la responsabilidad en la que incurre quien divulgue la información, oferta y publicidad que luego no se ajusta a la realidad del producto que se adquiere.

Antes al contrario, la norma indicada proclama una gran amplitud objetiva al incluir en la vinculación a «Toda» la información, oferta y publicidad, con el único límite de que tengan «relación con los bienes ofrecidos o servicios a prestar».

Se deduce de ello, sin gran dificultad, que podrá exigirse a la persona que resulte responsable civil de aquello que se divulgue, el cumplimiento del contenido de todo los que, teniendo relación con el bien o servicio, fue objeto de información, oferta o publicidad, sin exclusión o limitación de clase alguna. 


\section{Responsabilidad civil exigible: contractual y extracontractual}

No debe pasarse por alto que del artículo 95 que aquí se comenta, se desprende, literalmente, que siempre habrá un contrato de consumo, según su inciso final: «Dicha información formará parte del contrato de venta ${ }^{24}$ que se celebre entre el proveedor y el consumidor».

Sin embargo, es claro que ello sólo ocurrirá cuando quien incumpla el contenido de la información, oferta o publicidad sobre el producto adquirido sea el vendedor final, o el prestador del servicio de manera directa al consumidor, supuestos en los que, efectivamente, no existirá gran dificultad para integrar la publicidad comercial, o cualesquiera formas de la oferta, en el contrato, verbal o escrito, que se celebre con el consumidor.

Pero, ¿qué ocurre cuando es el fabricante, el importador o el distribuidor, quien realiza una campaña de publicidad cuyos productos no se ajustan a lo ofrecido, sin que el vendedor o prestador final del servicio haya sido quien «solicite, autorice o pague la difusión correspondiente»? No existe, en tales casos, vínculo contractual entre quien realiza la publicidad falsa o engañosa, y quien adquiere el producto.

En estos supuestos en los que la persona, generalmente, jurídica, encarga, dirige y costea la campaña de publicidad, al no tener relación con el consumidor, pero éste sufre el incumplimiento de lo ofrecido por aquella, la responsabilidad que nace habrá de tener carácter extracontractual, modalidad que disipa las trabas de la ausencia de relación entre anunciante y consumidor.

El artículo 95 del Reglamento, configurado, como se ha visto, con un carácter muy amplio, no prohíbe tal interpretación, que por otra parte, es la única posible para que pueda responder civilmente quien encarga o paga la publicidad pero no que nunca llega a contratar directamente con el consumidor, por lo que, además de que aquella «información» divulgada pueda ser parte del contrato, cuando éste exista, también deberá integrar el contenido objetivo de la responsabilidad civil extracontractual exigible al anunciante engañoso.

24 Pese a la dicción literal, que hace referencia al «contrato de venta», paradigma de los demás contratos tipificados en los Códigos, no cabe duda que además han de incluirse toda clase de contratos entre el vendedor, o especialmente, el prestador de servicios, con el consumidor. Aunque sea más abundante el contrato de compraventa, no es el único que celebran a diario los consumidores en sus relaciones cotidianas con toda clase de empresarios y profesionales. 
Esta responsabilidad extracontractual habrá de exigirse por la vía del artículo 2509 del Código civil de Nicaragua, como se ha dicho, al no mediar contrato entre el consumidor y la empresa que paga la publicidad. La divulgación de una información inexacta, a modo de publicidad comercial, dirigida ad incertam personam, que luego tienen la condición de consumidores cuando adquieren el bien o el servicio, encaja, a la perfección el supuesto de «dolo, falta, negligencia o imprudencia», e incluso en el «hecho malicioso», pues cualquiera de ellos puede originar un daño, esto es, incumplir lo prometido en la publicidad con la frustración de las expectativas del consumidor, lo que deriva en la obligación -extracontractual- de reparar tal daño y también los perjuicios que se hayan causado.

Cuando sea más de una la persona la que «solicite, autorice o pague la difusión», la responsabilidad de todas ellas tendrá carácter solidario, a tenor de los artículos 2510 y $2515 \mathrm{CCN}$, lo que supone una gran ventaja para el consumidor, que podrá reclamar todo el contenido de lo que se ofreció o prometió a través de la publicidad engañosa, falsa, o simplemente inexacta, a cualquiera de tales personas, a algunas o a una sola, optándose, generalmente, por la que sea más solvente patrimonialmente, claro está, según interese al consumidor.

\section{La vinculación publicitaria en el Código civil de Nicaragua}

\section{La denominada promesa contractual}

El Código civil de Nicaragua, al contrario que su homólogo español que no contiene referencia alguna sobre esta importante figura, regula la promesa unilateral en el artículo 2450: «El que hace una proposición puede retirarla mientras no haya sido aceptada por la otra parte; pero el contrato propuesto será válido, si la persona o quien se hizo la proposición, la acepta puramente antes de tener noticia de que había sido retirada».

A nuestro juicio, no cabe duda que el precepto es aplicable a toda oferta contractual, y por tanto, a la publicidad comercial realizada por cualquier medio, puesto que tal publicidad no es otra cosa que una promesa, que se integrará en el contrato, según la propia dicción literal del propio artículo $2450 \mathrm{CCN}$, si la persona a quien se hizo, es decir, todo potencial contratante, la acepta antes de que la oferta sea retirada. 
La promesa unilateral de contrato, y por tanto, la publicidad comercial que tiene tal carácter, se convierte así en un consentimiento contractual anticipado que se perfecciona con la aceptación, por lo que, a tenor del artículo $2449 \mathrm{CCN}$ : «desde que la estipulación se acepta, queda perfecto el contrato, salvo que la ley exija alguna otra formalidad; pero en todo caso se tendrá como una promesa exigible».

Además, como todo consentimiento, deberá reunir los caracteres propios de éste que se determinan en el artículo 2449 CCN, esto es, habrá de manifestarse libre y claramente, pero dicha «manifestación puede ser hecha de palabras, por telégrafo, teléfono, por escrito o por hechos de que necesariamente se deduzca». La enumeración, amplia desde luego, tiene la consideración de numerus clausus, es decir, tienen carácter enunciativo, y no cerrado, lo que permite otras muchas formas, en especial, en la época actual, a través de los medios que se derivan de las nuevas tecnologías, incluyendo, claro está, internet, el correo electrónico y la mensajería instantánea.

Pero si alguna duda quedara respecto de lo anterior, en particular porque se entendiese que ello sólo se aplica a la promesa realizada exclusivamente entre las partes contratantes, perfectamente identificadas, aquélla debería disiparse de manera absoluta a la vista de lo dispuesto en el artículo $2485 \mathrm{CCN}$, respecto de la promesa del tercero, que, como es sabido indica que: «La promesa del hecho de un tercero, cualquiera que sea el objeto del contrato, obliga al que la hace, con tal que ella aparezca con el carácter de contrato».

\section{Eficacia e interpretación contractual}

Si los contratos obligan, no sólo a lo expresamente pactado, sino, también, «a las consecuencias que la equidad, el uso o la ley hacen nacer de la obligación, según la naturaleza de ésta», tal como dispone el artículo $2480 \mathrm{CCN}$, siendo aquéllos «una ley para los contratantes», como dispone el precepto que le antecede, habrá que convenir que, sin necesidad de acudir a la ley (pues en el caso de los consumidores es clara al respecto), el propio uso y, en especial, la equidad, determinan que las afirmaciones que se realizan a través de la publicidad tengan el carácter de exigibles a quien las hace, pues, en otro caso, no podría entenderse la aplicación del principio de equidad, si se ofrece cualquier cosa con la clara intención de no cumplirlo jamás. 
¿O acaso no sería contrario a los más elementales principios de equidad anunciar mediante cualquier soporte publicitario unas determinadas características de un producto que se pone al mercado sin que luego, una vez concluido el contrato de consumo, coincidan los aspectos esenciales de lo que se divulgó con lo adquirido?

Y es que, la intención de las partes es decisiva, no sólo en la ejecución de los contratos, sino, de manera decidida, en la propia preparación de los mismos a través de la oferta. Por ello, el artículo 2496 CCN precisa que, en el contrato, «si las palabras aparecen contrarias a la intención evidente de los contratantes, prevalecerá ésta sobre aquellas», ratificándose en el artículo 2498 CCN esta intencionalidad de las partes («se propusieron contratar»). Es decir, si en la publicidad comercial se anuncia un bien o servicio con unas características determinadas, es evidente que quien la ofrece está manifestando la intención de las partes sobre el objeto de la obligación, por lo que, a nuestro juicio, si luego la letra del contrato no coincide con tal intención, ésta habrá de prevalecer.

\section{La publicidad falsa o engañosa como manifestación del dolo}

Determina el artículo 19 de la Ley 182 de Nicaragua que ${ }^{25}$ : «Se considera que hay engaño cuando: a) En cualquier tipo de información, comunicación, publicidad comercial, envases o etiquetas se utilicen textos, diálogos, sonidos, imágenes o descripciones que directa o indirectamente impliquen inexactitud, oscuridad, omisión, ambigüedad o exageración. b) Se induzca al consumidor a engaño, confusión o error sobre» sus aspectos esenciales ${ }^{26}$ :

Si bien, como ya se ha visto, el propio Reglamento de la Ley 182 determina en su artículo 95 que la información, oferta y publicidad vincula a quien la solicite, autorice o pague, lo que sirve de precepto legal donde basar la exigencia de su cabal y fiel cumplimiento, no es menos cierto que, además, la calificación legal

25 Se inicia el precepto con el siguiente texto: «La oferta, promoción y publicidad falsa o engañosa de productos, actividades o servicios constituye delito de estafa, sin perjuicio de otras responsabilidades penales y civiles».

26 Tales como: «a) El origen comercial geográfico del bien ofrecido; b) El lugar de prestación del servicio; c) Componentes o ingredientes del bien ofrecido; d) Los beneficios o implicancias del uso del producto o la contratación del servicio; e) Las características básicas del producto a vender o el servicio a prestar, tales como dimensión, cantidad, calidad, utilidad, durabilidad u otros; f) Fecha de elaboración y vida útil del bien; g) Los términos de garantías que se ofrezcan; h) El precio del bien ofrecido, las formas de pago y el costo al crédito», según el artículo 19 de la Ley y el 96 del Reglamento de ésta. 
como «engaño» de todas aquellas situaciones informativas o publicitarias que se han descrito, implica una evidente actuación dolosa por parte de quien la genera o propicia.

Basta para llegar a tal conclusión con la simple lectura del artículo 2469 CCN donde se establece la definición legal del dolo en el sistema civil de Nicaragua: «Hay dolo, cuando con palabras o maquinaciones insidiosas de parte de uno de los contratantes, es inducido el otro a celebrar un contrato que, sin ellas, hubiera hecho».

No es otra cosa lo que ocurre mediante la publicidad falsa o engañosa, pues cuando el consumidor adquiere un producto inducido por la publicidad, lo hace confiando en la realidad de ésta, de modo que sin las afirmaciones que contiene, o si conociera que aquellas no se ajustan a realidad, no hubiera celebrado el contrato.

Ratifica el criterio el artículo $2460 \mathrm{CCN}$ : «El dolo no vicia el consentimiento, sino cuando es obra de una de las partes y cuando además aparece claramente que sin él no hubiera habido contrato». Pero aunque no quedara viciado el consentimiento, el mismo precepto establece otras consecuencias de una contundencia extrema: «En los demás casos, el dolo da lugar solamente a la acción de daños y perjuicios contra la persona o personas que lo han fraguado o se han aprovechado de él».

Finalmente, la concurrencia del dolo, claramente aplicable a los supuestos de publicidad falsa o engañosa, permite dejar sin efecto el contrato, a tenor del artículo $2466 \mathrm{CCN}$ : "El dolo es causa de nulidad cuando los manejos usados por uno de los contratantes sean tales, que el otro no hubiera contratado sin los mismos ${ }^{27}$.

\section{El principio de buena fe y la doctrina de los actos propios}

En el Código civil de Nicaragua no se contiene una formulación expresa y genérica del principio de la buena fe, sin embargo, a lo largo de todo su cuerpo legal, se acude, de manera repetida y recurrente, al concepto de buena $\mathrm{fe}^{28}$.

27 No obstante, «para que el dolo produzca nulidad de los contratos, deberá ser grave y no haber sido empleado por las dos partes contratantes. El dolo incidental sólo obliga al que lo empleó, a indemnizar daños y perjuicios», según determina el artículo 2470 CCN. 
Ambas son magnitudes muy diferentes, aunque no es infrecuente confundir por ambas expresiones por la doctrina y la jurisprudencia de todos los países.

Por una parte, y en síntesis, la buena fe es un concepto jurídico indeterminado al que se refieren todos los ordenamientos desde tiempos inmemoriales, y consiste en «la convicción de actuar conforme a Derecho» ${ }^{29}$. Y por otra, también resumidamente, la buena fe es un principio general del Derecho que consiste en «un imperativo de conducta honesta, diligente, correcta», una regla de conducta «que exige a las personas de derecho una lealtad y una honestidad que excluya toda intención maliciosa». (IvON Loussuarn, 2004).

Esta segunda dimensión de la buena fe, como principio general del Derecho, cuya influencia se ha venido acrecentando a lo largo del último cuarto de siglo (CASEY, 1998), y se trata, en definitiva, de la honestidad llevada al terreno jurídico, implica «una serie de obligaciones que se tornan exigibles», pero

fe», en concreto, en los siguientes preceptos: art. 107 (matrimonio nulo contraído de buena fe), art. 238 (legitimación de los hijos del matrimonio nulo de buena fe), arts. 630, 631 y 634 (edificación de buena fe en terreno ajeno), art. 653 (confusión o mezcla de buena fe), art. 654 (empleo de materia ajena de buena fe), arts. 880, 888, 891, 899, 900 y 901 (adquisición de cosa ajena mediante posesión de buena fe), art. 993 (acción de indignidad contra terceros de buena fe), arts. 1.300 y 1.301 (ocupación de la herencia de buena fe), arts. 1.441, 1.443, 1.452 y 1.453 (reivindicación de la cosa al tercer poseedor de buena fe), art. 1.456 (acreedor que de buena fe recibe en prenda una cosa), art. 1.718 (definición de posesión de buena fe), art. 1.720 (presunción de buena fe de la posesión), arts. 1.743, $1.744,1.745,1.749,1.752,1.754,1.756,1.761,1.762,1.768,1.770$ y 1.790 (régimen jurídico del poseedor de buena fe), art. 1.866 (responsabilidad del deudor de buena fe) ), art. 1.893 (posesión del tercero de buena fe), art. 2.010 (acreedor que consumió la cosa de buena fe), art. 2.016 (pago de buena fe al poseedor del crédito), art. 2.025 (pago que aprovecha el acreedor de buena fe), art. 2.069 (cancelación de buena fe de un título necesario para el cobro), art. 2.073 (cobro indebido de buena fe), art. 2.074 (venta indebida de buena fe), art. 2.075 (restitución pago indebido de buena fe), art. 2.216 (acción rescisoria contra terceros poseedores de buena fe), art. 2.237 (adquiriente de buena fe en fraude de acreedores), art. 2.344.4 (indemnización al poseedor de buena fe como deuda de la masa), art. 2.568 (venta de cosa ajena de buena fe), art. 2.575 (primer poseedor de buena fe de lo vendido a varios), art. $2.746 .3^{\circ}$ (uso de inmueble por poseedor de buena fe), art. 3.239 (responsabilidad de la sociedad con el socio que actúa de buena fe), art. 3.306 (mandatario de buena fe), art. 3.355 (derechos de los terceros de buena de fe contra el mandante), art. 3.377 (obligación del gestor con el tercero de buena fe), art. 3.411 (obligación del mutuario de buena fe), art. 3.494 (heredero del depositario que de buena fe vende la cosa), art. 3.576 (buena fe e ignorancia de ambos contratantes del seguro), art. 3.614 (portador de buena fe de una obligación de juego o apuesta), art. 3.657 (responsabilidad del fiador con el tercero de buena fe), art. 3.770 (derecho del acreedor de buena fe en la extinción de la prenda) y art. 3.839 (derecho de los acreedores hipotecarios cuando el propietario entrega el bien a un adquiriente de buena fe).

29 Esta es la concepción de la buena fe, por ejemplo, en el campo de los derechos reales, así la buena fe legitima la posesión de un inmueble y permite la usucapión, «no es un estado de conducta sino un estado de conocimiento que nada tiene que ver con la maquinación o el engaño, sino con el creer o ignorar si la situación registral era o no exacta respecto de la titularidad dominical que se reclama», así la STS de España de 16 de febrero de 1981. 
además, «en la obligación de información a la contraparte sobre aspectos esenciales del negocio a celebrar, la obligación de no actuar en forma reticente», en particular, en lo que aquí se estudia, en la obligación de no contravenir con hechos las declaraciones contenidas, por ejemplo, en la publicidad comercial, cuya contravención y vulneración es causa de la nulidad del contrato(Rosch, 2000).

Finalmente, la regla venire contra factum proprium nulla conceditur, conocida como la doctrina de los actos propios (López MesA \& Rogel Vide, 2009; DíEzPicazo, 1963; Puig Brutau, 1951), ha sido definida muy acertadamente, de modo aplicable a la práctica totalidad de los ordenamientos jurídicos, como:

Un principio general del derecho, fundado en la buena fe que impone un deber jurídico de respeto y sometimiento a una situación jurídica creada anteriormente por la conducta del mismo sujeto, evitando así la agresión a un interés ajeno y el daño consiguiente (FUEYo LANERI, 1990).

A la vista de la anterior y omnicomprensiva definición de la doctrina de los actos propios, se evidencia que cuando el empresario ofrece mediante la publicidad comercial, a través de cualquier soporte, declaraciones públicas acerca de las cualidades o caracteres de los bienes y servicios que pone en el mercado, dicha actuación le impide actuar de manera contraria a tales declaraciones, que le vinculan, pues en otro caso, supondría que quien ha depositado la confianza en tales afirmaciones vería frustradas sus legítimas expectativas que han de ser protegidas por el Derecho.

\section{Breve recapitulación}

Una somera recapitulación de las anteriores líneas nos lleva a la exposición de unas muy sintéticas conclusiones que pueden resumirse en las siguientes:

1. La vinculación de la publicidad comercial por parte de quien la realiza no ha sido reconocida en Europa, con carácter normativo, hasta épocas muy recientes, si bien en el Derecho comunitario actual está plenamente vigente en los veintisiete países que conforman la Unión Europea.

2. En particular, en el Derecho español fue reconocida la integración publicitaria del contrato por la jurisprudencia en la década de los setenta, aplicando las 
normas clásicas sobre la Teoría General de Contrato contenidas en el Código civil, varios años antes de que el legislador la regulase.

3. No son muchos los países que regulan y reconocen de manera expresa el principio de integración del contrato mediante normas dictadas ad hoc para determinar la vinculación de la publicidad como parte exigible del contrato.

4. Sin embargo, existen mecanismos diversos contenidos en los principios y postulados de los Códigos civiles que permiten, sin dificultad, construir el principio de vinculación contractual de la publicidad con muy eficaces mecanismos.

5. El ordenamiento jurídico de la República de Nicaragua regula de manera expresa esta figura en las normas de protección a los consumidores, al determinar que en particular en el artículo 95 del Reglamento de 1999 aprobado por el Decreto 2187, que desarrolla la Ley núm. 182 de Defensa de los Consumidores de 1994 cuyo texto ha de calificarse, desde nuestro punto de vista, de manera muy positiva por su claridad enunciativa: «Toda información, publicidad u oferta al público, transmitida por cualquier medio o forma de comunicación, en relación con los bienes ofrecidos o servicios a prestar, vincula al proveedor que solicite, autorice o pague la difusión correspondiente. Dicha información formará parte del contrato de venta que se celebre entre el proveedor y el consumidor».

6. La vinculación de la publicidad al contrato que se reconoce de manera literal en la compraventa ha de entenderse, naturalmente, al resto de los contratos que se celebren en Nicaragua entre los empresarios o profesionales y los consumidores.

7. Si bien el Reglamento nicaragüense ceñiría la aplicación del principio de integración publicitaria del contrato tan sólo a los consumidores y usuarios, sin embargo, una interpretación adecuada de los preceptos del Código Civil de la República de Nicaragua permite extenderlo a cualesquiera otras operaciones jurídicas en las que no sean partes los sujetos que tienen la condición jurídica de consumidor.

8. El éxito de la eficacia práctica de esta norma de tan extraordinario alcance depende, básicamente, tanto de un perfecto conocimiento de esta figura y sus perfiles técnicos por parte de los juristas, en especial docentes, abogados y 
jueces, como de una adecuada divulgación social de este principio como uno de los derechos básicos, de carácter económico que tienen a su disposición los consumidores de Nicaragua.

-Universidad de Extremadura, Cáceres, España, Julio 2011.----

\section{Lista de referencias}

Acedo Penco, A. (2003). Nociones de derecho de consumo: aspectos de la protección jurídica de los consumidores en Extremadura. Cáceres: Servicio de Publicaciones de la Universidad de Extremadura.

Acedo Penco, A. (2007). La integración publicitaria del contrato como elemento de protección de los derechos de los consumidores que configuran la parte débil en los contratos, En El Derecho de contratos en los umbrales del siglo XXI: memorias de las Jornadas Internacionales de Derecho de Contratos celebradas en la Habana, Cuba, en el período 2001-2007. Academia Brasileira de Direito: São Paulo.

Albiez Dohrmann, K. J. (2002). La integración del Derecho de consumo contractual en el Código Civil: ¿una simple entelequia jurídica o algo más?. En Estudios jurídicos en homenaje al profesor Luis Díez-Picazo. vol. 1, (Semblanzas. Derecho civil. Parte general). Madrid: Editorial Civitas.

Arnau Moya, F. (2006). La vinculación contractual en la Ley 7/1995 de crédito al consumo (diez años de experiencias). En el Libro-Homenaje al profesor Manuel Amorós Guardiola, vol. 1.

Baladrón Pazos, A. J. \& Martínez Pastor, E. (2007). Publicidad irrespetuosa en Internet: La comunicación comercial como instrumento para el engaño en la Red. En Falsedad y comunicación: publicidad engañosa, información falsa, imagen manipulada. Servicio de Publicaciones de la Universidad de Málaga.

Benjamín Antonio (1997). Reflexiones sobre el principio de la vinculación contractual de la publicidad. En Responsabilidad por daños en el tercer milenio: homenaje al profesor doctor Atilio Aníbal Alterini. Teoría general del derecho de daños. Responsabilidades especiales. Derecho 
privado y procesal: perspectiva y prospectiva. Buenos Aires, Argentina: Abeledo-Perrot.

Casas Planes, M. D. (2007). La integración del contrato por la buena fe: sus efectos en la concurrencia entre la responsabilidad contractual y extracontractual en el derecho español. En El Derecho de contratos en los umbrales del siglo XXI: memorias de las Jornadas Internacionales de Derecho de Contratos celebradas en la Habana, Cuba, en el período 2001-2007, São Paulo: Academia Brasileira de Direito, MP Editora.

Casey, J, (1998). De la bonne foi et de la modération dans la formation du contrat, Recueil Dalloz, sec. Jurisprudence. (p. 208). Paris.

Clavería Gosálbez, L. H. (2002). Interpretación, calificación e integración del contrato. En Estudios jurídicos en homenaje al profesor Luis DíezPicazo. vol. 2, (Derecho civil, derecho de obligaciones). Madrid: Civitas.

Corrales García, E. (2000). La protección de los consumidores a través de la eficacia contractual de la publicidad. En Actualidad civil, La Ley, número 38, Madrid.

Cuesta García De Leonardo, A. (1996). El art. 8 LCU en la jurisprudencia. En Aranzadi Civil, 13,

De la Cuesta Rute, J. M. (1977). Régimen jurídico de la publicidad. Madrid: Tecnos.

Díaz Gómez, M. A. (2008). Ámbito objetivo y subjetivo de la integración publicitaria prevista en el art.61 del Texto Refundido de la Ley General para la Defensa de los Consumidores y Usuarios. Revista de derecho de la competencia y la distribución, (2) pp. 65-99.

Díez-Picazo, L. (2007). Fundamentos del Derecho Civil Patrimonial: Introducción a la Teoría del Contrato. Volumen Primero. (6 ${ }^{\mathrm{a}}$. Ed.). Cizur Menor (Navarra): Aranzadi.

Díez-Picazo, L. (1963). La doctrina de los actos propios. Barcelona: Bosch. 
Fueyo Laneri, F. (1990). Instituciones de Derecho civil moderno. Santiago de Chile: Editorial Jurídica de Chile.

Garcia Sais, F. (2005). La eficacia jurídica contractual de la publicidad en los contratos con consumidores, Revista de Derecho Privado del Instituto de Investigaciones Jurídicas, Universidad Autónoma de México. (9-10).

Ivon Loussuarn, M. (2004). La buena fe. En E. A. Pigrett (Comp.). Tratado de la buena fe en el derecho. Tomo II. Buenos Aires: La Ley.

Lasarte Álvarez, C. (1980). Sobre la integración del contrato: la buena fe en la contratación (en torno a la STS del 27 de enero de 1977, Revista de Derecho Privado, Madrid, p. 50.

Lema Devesa, C. (1990). La protección del consumidor en la Ley General de Publicidad. Curso sobre el nuevo Derecho del consumidor, Madrid.

López Mesa, M. J. \& Rogel Vide, C. (2009) La doctrina de los actos propios. Doctrina y jurisprudencia. Montevideo: B de F.

Martí, J. N., «La publicidad y el derecho-deber de información», en Estudios sobre Consumo. Madrid: Instituto Nacional del Consumo de España.

Martín García, M. del L. (2004). Aspectos publicitarios de la Ley de garantías en la venta de bienes de consumo. Revista de Derecho Privado. (88). Pp. 324-34.

Martínez Rodríguez, N. (2006). La vinculación contractual en la Ley 7/1995, de crédito al consumo, en Estudios de Derecho de obligaciones: homenaje al profesor Mariano Alonso Pérez. vol. 2. Madrid: La Ley.

Miquel Rodríguez, J. (2001) Problemática jurídica de la publicidad en Internet, en Comercio electrónico y protección de los consumidores. Madrid: La Ley.

Miranda Serrano, L. M. (2006). La protección del consumidor en la etapa anterior a la celebración del contrato: aspectos concurrenciales y negociables. en Estudios sobre Consumo. Madrid: Instituto Nacional del Consumo de España 
Montes Rodríguez, M.P. (1996). La publicidad engañosa en el art. 8.3 de la LGDCU (Ley General de Defensa de los Consumidores y Usuarios). En Estudios en homenaje a la profesora Teresa Puente. Vol. II, Valencia, España.

Morales Moreno, A. M. (1999). Declaraciones públicas y vinculación contractual (reflexiones sobre una propuesta de directiva), en Anuario de Derecho Civil. T 52, fasc. 1.

Pasquau Liaño, M. (1992). Comentario al artículo 8, en R. Bercovitz \& J. Salas (Dir.). Comentarios a la Ley General para la Defensa de los Consumidores y Usuarios (p. 164) Madrid: Editorial Civitas.

Pasquau Liaño, M. (2001). La protección de las legítimas expectativas del consumidor y la exigibilidad de las promesas publicitarias: una propuesta de superación del artículo 8 de la Ley de consumidores y usuarios, Revista de autocontrol publicitario. (56) p. 24.

Puig Brutau, J. (1951). Estudios de Derecho comparado. La doctrina de los actos propios. Barcelona.

Reyes López, M. J. (1997). El Carácter Vinculante de la Oferta y de la Publicidad en el Artículo 8 de la Ley General para la Defensa de los Consumidores y Usuarios. En Estudios sobre Consumo. Madrid: Instituto Nacional del Consumo de España.

Rivero González, M. D. (2003). Régimen jurídico de la publicidad en Internet y las comunicaciones comerciales no solicitadas por correo electrónico, Revista de Derecho Mercantil. (250) pp. 1587-1614.

Rosch, W. (2000). La bonne foi est un príncipe général du commerce international que les parties ne puevent ni exclure ni modifier, Recueil Dalloz. Sommaries comentés, (p. 449). Paris.

Sánchez del Castillo, V. (2007). La publicidad en Internet: régimen jurídico de las comunicaciones comerciales electrónicas. Las Rozas (Madrid): La Ley.

Soler Pascual, L. A. (2007). La vinculación contractual en el ámbito del consumo», Revista de la Facultad de Ciencias Sociales y Jurídicas de 
la Universidad Miguel Hernández, (2) (Ejemplar dedicado a las Nuevas Tecnologías) pp. 335-362.

Torres Lana, A. (1997). Derecho a la información y protección de los consumidores. En Aranzadi Civil, (18) p. 9 ss. 


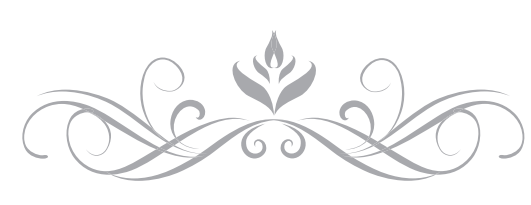

